\title{
Predicted normal values for maximal respiratory pressures in caucasian adults and children
}

\author{
SH WILSON, NT COOKE, RHT EDWARDS, SG SPIRO
}

From the Department of Respiratory Medicine, Rayne Institute, University College Hospital, London

ABSTRACT Maximal respiratory pressures at the mouth $\left(\mathrm{PE}_{\max }\right.$ and $\left.\mathrm{PI}_{\max }\right)$ have been measured in 370 normal caucasian children and adults. Age, height, and weight were recorded for all subjects and incorporated in a stepwise multiple regression analysis to determine prediction equations for the maximal respiratory pressures in the children and adults for both sexes. In men $\mathrm{PI}_{\max }$ and $\mathrm{PE}_{\max }$ were significantly correlated only with age $(\mathrm{p}<0.001$ and $<0.035$ respectively), whereas in women they were correlated with height $(\mathrm{p}<0.035$ and $<0.03)$. In both boys and girls $\mathrm{PI}_{\max }$ was related to weight $\left(p<0.0001\right.$ and $<0.01$ respectively) and $P E_{\max }$ to age $(p<0.001$ for both). The values for $\mathrm{PI}_{\max }$ and $\mathrm{PE}_{\max }$ in adults were lower than in previously reported series, but in children the values obtained were similar to those reported for several smaller series.

In recent years interest has been rekindled in methods for measurement of respiratory muscle function in patients with neuromuscular disease. One of the simplest non-invasive measurements is that of maximal pressures, generated at the mouth, after full inspiration and full expiration-that is, maximal expiratory pressure $\left(\mathrm{PE}_{\max }\right)$ and maximal inspiratory pressure ( $\left(\mathrm{PI}_{\max }\right)$.

These pressures have been measured with a mercury manometer ${ }^{1}$ and by pressure gauges. ${ }^{2}$ Normal values for adults have been collected by Ringqvist ${ }^{3}$ and Black and Hyat ${ }^{2}$ and measurements in patients with neuromuscular disease and obstructive lung disease have also been reported. ${ }^{45}$ Inkley et al ${ }^{6}$ studied a group of 38 American boys with Duchenne muscular dystrophy and compared the results with values from 66 normal schoolboys (aged 6-14 years), and Cerretelli et al' studied a small group of 12 year old children.

As part of the investigation of patients with neuromuscular disease we measured $\mathrm{PE}_{\max }$ and $\mathrm{PI}_{\max }$ in a group of normal subjects and noted a wide range of normal values from these pressures in published reports. In addition, since there are limited data on $\mathrm{PI}_{\max }$ and $\mathrm{PE}_{\max }$ values in children, a larger and more comprehensive group of normal subjects

\footnotetext{
Address for reprint requests: Dr SG Spiro, Department of Respiratory Medicine, Rayne Institute, University College Hospital, London WC1E 6JG.
}

Accepted 7 December 1983 was studied in an attempt to determine normal values for British caucasian adults and children. The age range of our subjects was 7-70 years.

\section{Methods}

\section{MEASUREMENTS}

Apparatus

The apparatus was based on that used by Black and Hyatt. ${ }^{2}$ Two bronze Bourdon type gauges, one with a pressure range of $0-380 \mathrm{~cm} \mathrm{H}_{2} \mathrm{O}$ for expiratory pressures and one with a vacuum range of $0-250 \mathrm{~cm}$ $\mathrm{H}_{2} \mathrm{O}$ for inspiratory pressures, were connected via a brass $\mathrm{E}$ tube. The central limb of this $\mathrm{E}$ tube was connected to a copper tube $3 \mathrm{~cm}$ in diameter and $30 \mathrm{~cm}$ in length, with a rigid plastic flanged mouthpiece (Airmed Ltd) and a small air leak $15 \mathrm{~cm}$ from the mouthpiece. The outside limbs of the $E$ tube each incorporated a brass tap, proximal to the gauge, so that each gauge could be used independently. The gauges were manufactured for our specific purpose and medically cleaned and calibrated over the range -200 to $+250 \mathrm{~cm} \mathrm{H}_{2} \mathrm{O}$ in the factory before despatch. The calibration was linear over the whole of the working range and pressures were checked regularly with standard water manometers over the range -150 to $+220 \mathrm{~cm} \mathrm{H}_{2} \mathrm{O}$.

All pressures were measured without a nose clip and with the subject seated. $\mathrm{PI}_{\max }$ was measured at residual volume after maximal expiration and $P E_{\max }$ at total lung capacity after maximal inspiration. The 
manoeuvre was repeated at least three times and until two identical readings were obtained. Pressures had to be maintained for at least one second. An interval of about one minute occurred between these efforts. A small leak in the circuit was necessary during both manoeuvres to prevent generation of high buccal pressures and in addition the subject held the cheeks with one hand during the manoeuvre. Children from 7 years were capable of performing the correct manoeuvre with ease.

Age, height and weight were also recorded for each subject.

\section{SUBJECTS}

We studied 135 caucasian adults aged over 18 years (table 1). All were volunteers; many were recruited from hospital staff. None had a history of chest disease or any chronic illness and none was having any regular treatment. A few were cigarette smokers and some ex-smokers, but no distinction was made between smokers and non-smokers. We also studied 235 children (distribution shown in table 1) from several schools. They were selected by teachers and all parents were informed of the tests and gave informed consent on behalf of their children. No child had any history of any chronic illness, in particular asthma, and none was having any regular medication.

\section{STATISTICAL METHODS}

In all subjects the values for the maximum respiratory pressures were plotted against the three variables measured (height, age, and weight), a stepwise multiple regression analysis ${ }^{8}$ being used. This analysis was used to obtain prediction equations for the maximum respiratory pressures. The three variables were included in the multiple regression analysis for all groups but a variable was included in the prediction equation only if the multiple correlation coefficient was significant $(p<0 \cdot 05)$.

The overall accuracy of the prediction equation was reflected by the square of the multiple correlation $\left(R^{2}\right) . R^{2}$ is the proportion of variation explained by variables included in the regression equation and is an index of the strength of the relationship. Student's unpaired $t$ test was also used for comparisons between groups of subjects.

\section{Results}

From a comparison of the group mean values (table 2) men can be seen to have generated higher pressures than women; for $\mathrm{PE}_{\max }$ the female value was $60 \%$ of the male value, for the $\mathrm{PI}_{\max } 69 \%$. These differences were significant $(p<0.001)$, whereas there was no significant difference between the age of the groups. Both $\mathrm{PE}_{\max }$ and $\mathrm{PI}_{\max }$ were significantly lower in girls than in boys, the means being respectively $83 \%$ and $83 \%$ of the boys' values ( $p<0.001$ : table 2). In both adults and children, values were lower for $\mathrm{PI}_{\max }$ than for $\mathrm{PE}_{\max }$ (on average overall $\mathrm{PI}_{\max }$ was $79 \%$ of $\mathrm{PE}_{\max }$ ). Repeated measurements carried out in five subjects over five days gave a coefficients of variation for $\mathrm{PE}_{\max }$ of $\mathbf{7 . 1 \%}$ and for $\mathrm{PI}_{\max }$ of $\mathbf{1 0 . 2 \%}$.

Table 3 shows the regression equations for prediction of $\mathrm{PE}_{\max }$ and $\mathrm{PI}_{\max }$ in adults and children, calculated by stepwise multiple regression analysis. The complete data with values of $\mathbf{R}^{2}$ are given in table 4 . For example, if we take the variables included in the multiple regression analysis for $\mathrm{PI}_{\max }$ in men (table 4), only age has a significant correlation coefficient and addition of the other variables, height and weight, does not result in significance or increase $R^{2}$

Table 1 Age distribution of the subjects

\begin{tabular}{|c|c|c|c|c|c|c|c|}
\hline \multirow[b]{2}{*}{ Age (y) } & \multicolumn{3}{|c|}{ Children } & \multicolumn{4}{|l|}{ Adults } \\
\hline & $7-9$ & $10-14$ & $15-17$ & $18-29$ & $30-39$ & $40-49$ & $\geqslant 50$ \\
\hline $\begin{array}{l}\text { Males (n) } \\
\text { Females (n) }\end{array}$ & $\begin{array}{l}38 \\
22\end{array}$ & $\begin{array}{l}75 \\
60\end{array}$ & $\begin{array}{l}24 \\
16\end{array}$ & $\begin{array}{l}14 \\
30\end{array}$ & $\begin{array}{l}18 \\
21\end{array}$ & $\begin{array}{r}8 \\
18\end{array}$ & $\begin{array}{r}8 \\
18\end{array}$ \\
\hline
\end{tabular}

Table 2 Significance of the sex differences in mean maximum respiratory pressures in adults and in children (values are means with standard deviation in parentheses)

\begin{tabular}{|c|c|c|c|c|c|}
\hline Group (n) & Age (y) & Height $(\mathrm{cm})$ & Weight $(\mathbf{k g})$ & $P E_{\max }\left(\mathrm{cm} \mathrm{H}_{2} \mathrm{O}\right)$ & $P I_{\max }\left(\mathrm{cm} \mathrm{H}_{2} \mathrm{O}\right)$ \\
\hline $\begin{array}{l}\text { Men (48) } \\
\text { Women (87) } \\
\text { Significance of } t\end{array}$ & $\begin{array}{l}34 \cdot 7(14) \\
36 \cdot 8(13) \\
\text { NS }\end{array}$ & $\begin{array}{l}179(6) \\
163(7) \\
p<0.01\end{array}$ & $\begin{array}{l}74.5(8.5) \\
61.4(9) \\
p<0.01\end{array}$ & $\begin{array}{l}148(34) \\
93(17) \\
p<0.001\end{array}$ & $\begin{array}{c}106(31) \\
73(22) \\
\mathrm{p}<0.001\end{array}$ \\
\hline $\begin{array}{l}\text { Boys (137) } \\
\text { Girls (98) } \\
\text { Significance of } t\end{array}$ & $\begin{array}{l}11 \cdot 1(2 \cdot 2) \\
11 \cdot 6(2 \cdot 5) \\
\text { NS }\end{array}$ & $\begin{array}{l}149(15) \\
147(16) \\
\text { NS }\end{array}$ & $\begin{array}{l}41(12) \\
40.5(12) \\
\text { NS }\end{array}$ & $\begin{array}{c}96(23) \\
80(21) \\
p<0.001\end{array}$ & $\begin{array}{c}75(23) \\
63(21) \\
\mathrm{p}<0.001\end{array}$ \\
\hline
\end{tabular}


Table 3 Prediction equations for maximal respiratory pressures in adults (over 18 years) and children (7-17 years)

\begin{tabular}{lcc}
\hline Group & $\mathrm{PI}_{\max }\left(\mathrm{cm} \mathrm{H}_{2} \mathrm{O}\right)$ & $P E_{\max }(\mathrm{cm} \mathrm{H} \mathrm{O})$ \\
\hline Men & $142-\left(1.03 \times \mathrm{Age}^{*}\right)$ & $180-\left(0.91 \times \mathrm{Age}^{*}\right)$ \\
Women & $-43+\left(0.71 \times \mathrm{Ht}^{\dagger}\right)$ & $3.5+\left(0.55 \times \mathrm{Htt}^{+}\right)$ \\
Boys & $44.5+(0.75 \times \mathrm{Wt \ddagger})$ & $35+\left(5.5 \times \mathrm{Age}^{*}\right)$ \\
Girls & $40+(0.57 \times \mathrm{Wt})$ & $24+\left(4.8 \times \mathrm{Age}^{*}\right)$ \\
\hline
\end{tabular}

*Age in years.

tHeight in centimetres.

¥Weight in kilograms.

by a significant amount. The multiple correlation squared (table 4) represents the cumulative "weight" each variable exerts on the regression equation for the prediction of $\mathrm{PE}_{\max }$ and $\mathrm{PI}_{\max }$ for each group.

\section{Discussion}

In view of the very wide range of maximal respiratory pressures reported in several small studies, we set out to obtain a set of prediction values for maximal respiratory pressures in both adults and children so that $\mathrm{PE}_{\max }$ and $\mathrm{PI}_{\max }$ could be used to assess respiratory muscle function in adults and children with neuromuscular disease. As these patients often present in their teens it was also important to obtain data for this age range. No reference values have previously been available which fully covered the age range in which clinical measurement would be valuable.

Our measurements of maximal respiratory pressures in adults are lower than many previously published values ${ }^{2}$ (see also table 5). The reason for the differences in values obtained in the adult groups is not clear. Black and Hyatt, ${ }^{2}$ whose results were lower than those of Ringqvist, ${ }^{3}$ thought it might have been because the latter used the best of many attempts, sometimes more than 20 , while they used the best of two. Ringqvist ${ }^{3}$ also used a group of military conscripts. In fact, the subjects in Ringqvist's study were pushed to such great lengths that some suffered from spontaneous nose bleeding and conjunctival haemorrhages as a result of their efforts. Gibson et al, ${ }^{9}$ using identical methods to those of this study, collected data from a small group of 10 normal caucasian women and obtained a range considerably lower than those of Ringqvist ${ }^{3}$ and Black and Hyatt ${ }^{2}\left(\mathrm{PE}_{\max } 67-140 \mathrm{~cm} \mathrm{H} \mathrm{H}_{2} \mathrm{O}\right.$ and $\mathrm{PI}_{\max }$ $35-95 \mathrm{~cm} \mathrm{H}_{2} \mathrm{O}$ ), but very similar to our results.

Our values for boys and girls are similar to those for the two groups of twenty 12 year old boys and girls of Cerretelli et al (table 5). As in adults, the equivalent values for $\mathrm{PE}_{\max }$ and $\mathrm{PI}_{\max }$ were lower in girls than in boys. The only other study in children ${ }^{6}$ included 66 normal boys aged 6-14 years. No mean data were provided but the range was similar to that

Table $4 R^{2}$ and significance values of each additional variable used to predict maximum respiratory pressures in a stepwise multiple regression analysis

\begin{tabular}{|c|c|c|c|c|}
\hline & Step & Variable & $\begin{array}{l}R^{2} \text { expressed as a } \\
\text { cumulative percentage }\end{array}$ & Significance \\
\hline \multirow{2}{*}{ MEN } & $\mathrm{PI}_{\max } \quad \begin{array}{l}1 \\
2 \\
3\end{array}$ & $\begin{array}{l}\text { Age } \\
\text { Height } \\
\text { Weight }\end{array}$ & $\begin{array}{l}21 \\
22 \\
25\end{array}$ & $\begin{array}{l}0.001 \\
0.434 \\
0.152\end{array}$ \\
\hline & $\mathrm{PE}_{\max } \frac{1}{2}$ & $\begin{array}{l}\text { Age } \\
\text { Weight } \\
\text { Height }\end{array}$ & $\begin{array}{l}14 \\
15 \\
15 \cdot 5\end{array}$ & $\begin{array}{l}0.009 \\
0.532 \\
0.568\end{array}$ \\
\hline \multirow{2}{*}{ WOMEN } & $\begin{array}{ll} & \\
P_{\max } & 2 \\
3\end{array}$ & $\begin{array}{l}\text { Height } \\
\text { Weight } \\
\text { Age }\end{array}$ & $\begin{array}{l}5 \cdot 1 \\
6 \cdot 4 \\
9 \cdot 8\end{array}$ & $\begin{array}{l}0.035 \\
0.270 \\
0.084\end{array}$ \\
\hline & $\mathrm{PE}_{\max } \frac{1}{2}$ & $\begin{array}{l}\text { Height } \\
\text { Age } \\
\text { Weight }\end{array}$ & $\begin{array}{l}5.4 \\
6.2 \\
8.0\end{array}$ & $\begin{array}{l}0.031 \\
0.392 \\
0.209\end{array}$ \\
\hline \multirow{2}{*}{ BOYS } & $\begin{array}{ll}\mathrm{PI}_{\max } & 1 \\
2 \\
3\end{array}$ & $\begin{array}{l}\text { Height } \\
\text { Age } \\
\text { Height }\end{array}$ & $\begin{array}{l}15 \cdot 8 \\
16 \cdot 2 \\
16 \cdot 3\end{array}$ & $\begin{array}{c}<0.0001 \\
0.399 \\
0.740\end{array}$ \\
\hline & $\mathrm{PE}_{\max } \frac{1}{2}$ & $\begin{array}{l}\text { Age } \\
\text { Weight } \\
\text { Height }\end{array}$ & $\begin{array}{l}35 \cdot 6 \\
37 \cdot 1 \\
37 \cdot 5\end{array}$ & $\begin{array}{c}<0.0001 \\
0.077 \\
0.584\end{array}$ \\
\hline \multirow{2}{*}{ GIRLS } & $P I_{\max }{ }^{*} 1$ & Weight & 10.8 & 0.01 \\
\hline & $\mathrm{PE}_{\max }{ }^{*} \frac{1}{2}$ & $\begin{array}{l}\text { Age } \\
\text { Weight }\end{array}$ & $\begin{array}{l}34.6 \\
34.9\end{array}$ & $\begin{array}{c}<0.0001 \\
0.495\end{array}$ \\
\hline
\end{tabular}

*The significance of a variable was not calculated if it improves $R^{2} \%$ by less than 0.1 . 
Table 5 Normal ranges of maximum respiratory pressures in adults and children in different studies

\begin{tabular}{|c|c|c|c|c|c|}
\hline \multirow[t]{2}{*}{$n$} & \multicolumn{2}{|c|}{ Mean age $(y)$} & $P E_{\max }$ & $P I_{\max }$ & Source \\
\hline & Mean & Range & \multicolumn{3}{|c|}{$\operatorname{Mean}(\mathrm{SD})\left(\mathrm{cm} \mathrm{H}_{2} \mathrm{O}\right)$} \\
\hline \multicolumn{6}{|l|}{ MEN } \\
\hline $\begin{array}{l}100 \\
60 \\
48\end{array}$ & $34 \cdot 7$ & $\begin{array}{l}18-83 \\
20-54 \\
19-65\end{array}$ & $\begin{array}{l}237(46) \\
233(42) \\
148(34)\end{array}$ & $\begin{array}{l}130(32) \\
124(22) \\
106(31)\end{array}$ & $\begin{array}{l}\text { Ringqvist }{ }^{3} \\
\text { Black and Hyatt }{ }^{2} \\
\text { Present series }\end{array}$ \\
\hline $\begin{array}{l}\text { WOMEN } \\
100 \\
60 \\
87\end{array}$ & $36 \cdot 8$ & $\begin{array}{l}18-83 \\
20-54 \\
18-65\end{array}$ & $\begin{array}{r}165(30) \\
152(27) \\
93(17)\end{array}$ & $\begin{array}{l}98(25) \\
87(16) \\
72.9(22)\end{array}$ & $\begin{array}{l}\text { Ringqvist }{ }^{3} \\
\text { Black and Hyatt }{ }^{2} \\
\text { Present series }\end{array}$ \\
\hline $\begin{array}{c}\text { BOYS } \\
66 \\
20 \\
137 \\
\text { GIRLS }\end{array}$ & $\begin{array}{l}12 \\
11 \cdot 1\end{array}$ & $\begin{array}{c}6-14 \\
12 \dagger \\
7-17\end{array}$ & $\begin{array}{l}70-201^{*} \\
96 \cdot 3(23 \cdot 3) \\
95 \cdot 7(23)\end{array}$ & $\begin{array}{l}20-123^{*} \\
76 \cdot 5(17 \cdot 4) \\
75 \cdot 4(23)\end{array}$ & $\begin{array}{l}\text { Inkley et al } \\
\text { Cerretelli et al } \\
\text { Present series }\end{array}$ \\
\hline $\begin{array}{l}20 \\
98\end{array}$ & $\begin{array}{l}12 \\
11 \cdot 6\end{array}$ & $\stackrel{12 \dagger}{7-17}$ & $\begin{array}{l}88 \cdot 0(16) \\
80-3(21)\end{array}$ & $\begin{array}{l}66 \cdot 5(19 \cdot 6) \\
63 \cdot 1(21)\end{array}$ & $\begin{array}{l}\text { Cerretelli et al } \\
\text { Present series }\end{array}$ \\
\hline
\end{tabular}

*No mean data given in paper.

$\dagger$ All children studied aged 12 years.

of Cerretelli et $a l^{7}$ and of the present series (table 5).

Cook $e t a^{10}$ have shown the difficulty of preventing air leaks at the mouth when pressures of more than $150 \mathrm{~cm} \mathrm{H}_{2} \mathrm{O}$ are produced and conventional mouthpieces are used. We found the rigid plastic flanged mouthpieces were comfortable for the subjects, and by creating pressure on the cheeks during the manoeuvre high pressures could be maintained without evidence of leaks. The coefficient of variation of $\mathrm{PE}_{\max }$ and $\mathrm{PI}_{\max }$ obtained with our technique and apparatus in normal subjects was similar to that recorded by Black and Hyatt. ${ }^{2}$

Our results show that respiratory pressures in men are related to age; for women, however, a significant relationship was shown only with height. This may be explained by the fact that muscle mass and therefore strength fall with increasing age in men, their peak being in the second and third decade, while in women overall strength may not be related to age to such an extent. In children $\mathrm{PI}_{\max }$ was correlated with weight and $P E_{\max }$ with age. ${ }^{1}$

The measurement of maximal respiratory pressure allows a simple, reproducible, and rapid assessment of respiratory muscle function which is extremely useful in following the progression of respiratory weakness in patients with neuromuscular disease. $^{26}$ The prediction values from this study allow interpretation of serial measurements of $\mathrm{PE}_{\max }$ and $\mathrm{PI}_{\max }$ in patients with neuromuscular disease from presentation, often as teenagers, through adult life.

SHW had a research fellowship from Sandoz Ltd and NTC a research fellowship from the Sir Jules
Thorn Charitable Trust. We are grateful to Miss A Betchley for typing the manuscript.

\section{References}

' Brodey AW, Wander HJ, O'Halloran RS, Connolly JJ, Schwertley FW. Correlations, normal standards and interdependence in tests of ventilatory strength and mechanics. Am Rev Respir Dis 1964;89:214-35.

${ }^{2}$ Black LF, Hyatt RE. Maximal respiratory pressures: Normal values and relationship to age and sex. Am Rev Respir Dis 1969;99:696-702.

${ }^{3}$ Ringqvist T. The ventilatory capacity in healthy subjects: an analysis of causal factors with special reference to the respiratory forces. Scand J Clin Lab Invest $1966 ; 18$, suppl 88:8-170.

${ }^{4}$ Black LF, Hyatt RE. Maximal respiratory pressures in generalised neuromuscular disease. Am Rev Respir Dis 1971;103:641-50.

${ }^{5}$ Byrd RB, Hyatt RE. Maximal respiratory pressures in chronic obstructive lung disease. Am Rev Respir Dis 1968;98:848-56.

- Inkley SR, Oldenburg FC, Vignos PJ. Pulmonary function in Duchenne muscular dystrophy related to stage of disease. Am J Med 1974;56:297-306.

' Cerretelli P, Brandi G, Brambilla I. Il massino lavoto potenziale dell' apparatus respiratocio come phoro di funzionaleta nei hogazzi. Minerva Medica 1959; 50:2499-501.

${ }^{8}$ Nie NH, Hull CH, Jenkins JG, Steinbrenner K, Brent DH. Statistical package for the social sciences. 2nd ed. New York: McGraw-Hill Book Company, 1975.

${ }^{9}$ Gibson GJ, Edmonds JP, Hughes GRV. Diaphragm function and lung involvement in systemic lupus erythematosus. Am J Med 1977;63:926-32.

${ }^{10}$ Cook CD, Mead J, Orzalesi MM. Static volume-pressure characteristics of the respiratory system during maximum efforts. J Appl Physiol 1964; 19:1016-21. 